Parliament, the press, and the national medical colleges, for justice from the authorities. The late Mr. Butler, of her Majesty's brig-of-war $A r a b$, and the late Mr. Duncan, of her Majesty's brig of-war Persian, both naval assistant-surgeons, have died of fever within the last three years, contracted from fever cases of their respective ships-the former officer in China, the latter officer in the West Indies. Mr. Butler bad for some time to relinquish his hammock at 4 A.M., that it might be lashed up and taken on the upper deck. In each of these brigs-of war there was a spare cabin. It is said Mr. Butler occupied it in the $A$ rab for some time; but at the caprice of Commander Morris he was studenly deprived of this accommodation. In the case of the Persian, which ship is now in commission, but under another commander-and an agreeable change for all on board-the present assistant-surgeon has a cabin. Commander Bulman, who invalided from the command of the Persian, was not popular with the junior medical department, and did everything he could to keep the assistant-surgeon from a cabin! Shame! -shame! Your readers will recollect that Admiral Berkeley has stated in the House of Commons, that it "was totally impossible to provide these young men with cabins in brigs-ofwar;" and after such a statement from a member of the legislature, a flag officer of the British navy, and a Lord of the Admiralty, there is but one opinion of such a man's veracity. To impose on the House of Commons is a breach of the privileges of that house, and wherefore is it tolerated?

The last three years have witnessed important changes as respects the feeling of parliament towards army and naval medical men, and an able editorial article appeared in the Times of the $23 \mathrm{rd}$ of June, 1849 , in advocacy of the military order of the Bath, and of ward-room privileges for naval assistantsurgeons.

Since that period, a majority of eight in Parliament has decided, on the motion of Captain Boldero,-"That the accommodation provided for the assistant-surgeons on board her Majesty's ships of war is inadequate and insufficient for securing the full benefit of their professional service;"-which vote is evaded by the Admiralty. The stringent and decided expressions of an order in council of 1805, are violated for more than 45 years. The conduct of successive Boards of Admiralty has been inconsistent with their duty to their sovereign's commands. They refuse to recognise the sacred obligations of an order in council, or a vote and censure of Parliament, and in their circular respecting naval assistant-surgeons they practically and effectually evade the vote of the Commons of 1850 . They blow "hot and cold," and thus sanction contradictions and anomalies. Naval assistant-surgeons, be firm without display! Be energetic and untining in quiet agitation for a cabin, a servant, a seat at the lientenant's table, two epaulettes, and a higher rate of half and full pay!

Chippenham, 1852 ,

Antods Justitis.

\section{FATAL EFFECTS OF THE DO-NOTHING SYSTEM.}

\section{To the Editor of THE Laxcet.}

Sir,-I was sent for a few days since to see an old lady. whom a twelvemonth or more back I had watched through one of the severest bronchial attacks I think I had ever seen; she was, however, after considerable care and trouble on my part, restored to as much health as an emphysematous lung would allow. A few days ago, after exposure, a recurrence, but a slighter one, of the attack took place. By sinapisms, ether, \&c., she appeared to be benefiting herself, when a Lady Bountiful suggested a reliance on the following plan of treatment:- Two globules of belladonna to be taken two successive mornings, and on the third a silica globule; and for fear of the powerful effects these might produce, abstinence from further globules, for a day or two, was recommended. That solace of advancing age, tea, was to be omitted, as being too strong a stimulant, and cocoa substituted in its place. Need I hardly tell you, this do-nothing humbug was followed by rapid sinking, and when I saw her (for honesty and narrowness of means prevented my being sent for until the sudden change produced alarm, I found her insensible, in a state approaching orthopnce; her face livid; wrist almost pulseless; her lungs full of mucus; her breathing irregular, and heart now and then hesitating whether it should beat again. To get down a little ether was all that was left to me, but without effect, for shortly after, the patient ceased to breathe.

Now, Sir, without assuming for our "allopathic measures" an omnipotence they profess not to possess, or wishing to assert, that if relied on in the present case a more propitious result would infallibly have followed,-for we all know, at such a season as advancing life, how fearfully frequent and fatal are these attacks, - I would ask any at all experienced in these diseases, what different result could have been expected from a recourse to that fearful quackery, the globulism of the present day. Few but have had experience of the value of timely measures; few but must have witnessed how quickly depressed the powers, how sudden the changes in the lung diseases of the aged; how necessary to support, by nourishments, and even frequent stimulants, those vital powers by which alone the too-surely fatal accumulation of mucus in the air-tubes can be prevented. It was with a feeling of this kind, that quackery in the present instance, by its omissions, rather than commissions, has induced or hastened on the fatal issue, that on being applied to for a certificate, $I$ thought it right to back it with the following memorandum:-

"I think it right to add, that I did not see the above case until very shortly before death, when she was insensible and rapidly sinking, a reliance on homoeopathic globules having prevented recourse to those active measures her state required, leading, in conjunction, at her advanced age, with the abstinence enjoined, to sudden sinking. I beg to state dis tinctly, it is not my opinion these globules killed her, as $I$ believe them utterly useless and inert, but that they were indirectly the cause of death, by preventing a recourse to those measures of activity, to which previous attacks had yielded, and which, from the statement of those around, appeared to have been benefiting her in the present attack until the above quackeries were recommended by a non-medical friend."

I fear, Sir, notwithstanding your severe and clever articles upon the subject, it still remains an undecided point how this at present prevailing homœopathic pestilence should be treated and opposed: whether it is better to pass by it in disgust, with the charitable expectation, that with somewhat more of rope the monster may ultimately destroy itself whether to treat it with homœopathic or allopathic doses of abuse, or whether to get oneself at once into nothing less than a most towering passion, is still I think in question; probably what O'Connell denominated "peaceful agitation" would bes answer our dignified position and purpose; and I have troubled you with the above case, solely with the view of hinting to " occasional correspondents" that a publication of a few cases of malpraxis, (and they are not a few, $-I$ have heard of many, and have regretted they are not in print,) plainly stated, " nothing extenuate or aught set down in malice," of the fatal effects of the neglect engendered by the system; and the com. bating their very numerous and grave absurdities, by good. tempered appeals to reason and common sense, would probably afford the best means of exposing their letiferous dogmas, and disabusing the public mind from any further reliance on their formidable globules.

Clapham-road, Dec. 1851.

H. K. OWEY.

\section{MEETINGS OF THE MEDICAL SOCIETIES IN} LONDON DURING THE ENSUING WEEK.

Nоте.-When the day of the month is not specified, no meetings take place.

\begin{tabular}{|c|c|c|}
\hline Societies. & & $\begin{array}{l}\text { Days of } \\
\text { Meeting. }\end{array}$ \\
\hline Epidemiological, 53, Berners-street & 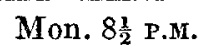 & \\
\hline Chemical, 5, Cavendish-square...... & Mon. 8 P.M. & \\
\hline Medico-Botanical, 32, Sackville-st. & Tuesday. & Jan. 13 \\
\hline $\left.\begin{array}{c}\text { Pathological, } 33, \text { George-street, } \\
\text { Hanover-square................... }\end{array}\right\}$ & $\begin{array}{l}\text { Tues. } \gamma_{\overline{1}} \text { P.M. } \\
\text { Tues. } 8 \text { P.M. }\end{array}$ & \$) \\
\hline $\begin{array}{l}\text { Hunterian, 4, Bloomfield-street, } \\
\text { Finsbury ............................ }\end{array}$ & Wed. 8 P.M. & \\
\hline Pharmaceutical, 17, Bloomsbury-sq. & 9 P.м. & \\
\hline Harveian, 64, Edgware-road ... & Thurs. 8 P.ar. & \\
\hline $\left.\begin{array}{l}\text { Western Medical and Surgical, } \\
44, \text { Sloane-street ................... }\end{array}\right\}$ & Fri. 8 P.M. & 16 \\
\hline $\begin{array}{l}\text { Medical Society of London, } 32 A, \\
\text { George-street Hanover-square }\end{array}$ & Sat. 8 P.M. & \\
\hline
\end{tabular}

Medicar Benevolence.-Dr. Chadwick has lately presented $£ 100$ to the Bolton Infirmary. 